\title{
Microbial and Sensory Stability of Cauliflower for 180 Days Preserved Through Hurdle Technology
}

\author{
Jyoti Sinha1*, Ena Gupta1, Prashasti Tripathi' ${ }^{1}$ and Ramesh Chandra ${ }^{2}$
}

${ }^{1}$ Centre of Food Technology, University of Allahabad, Allahabad, U.P, India

${ }^{2}$ Warner School of Food and Dairy Technology, Sam Higginbottom Institute of Agriculture, Technology and Sciences, (Deemed-To- Be- University, Formerly AAI-DU), Allahabad, U.P, India

\begin{abstract}
Fresh cauliflower were preserved by combinations of hurdles i.e. blanching through different treatments-

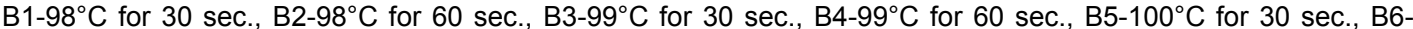
$100^{\circ} \mathrm{C}$ for $60 \mathrm{sec}$., followed by dipping into $0.25 \%$ potassium metabisulphite for 10 minutes, among above 6 treatments, successful blanching treatment was selected. Then blanched cauliflower were steeped into different concentrations and combinations of preservatives - P0 (Control sample- fresh without treatment), P1 $[8 \%$ Salt +500 ppm (parts per million) Potassium metabisulphite +100 ppm Sodium benzoate)], P2 (10\% Salt+400 ppm Potassium metabisulphite +200 ppm Sodium benzoate), P3(12\% Salt+300 ppm Potassium metabisulphite +300 ppm Sodium benzoate), P4 ( $8 \%$ Salt $+0.3 \%$ Citric acid +300 ppm Potassium metabisulphite +300 ppm Sodium benzoate), P5 (10\% Salt $+0.2 \%$ Citric acid +400 ppm Potassium metabisulphite +200 ppm Sodium benzoate) and P6 (12\% Salt $+0.1 \%$ Citric acid +500 ppm Potassium metabisulphite +100 ppm Sodium benzoate). Steeped cauliflower were aseptically packed into food grade polyethylene pouches and stored at two temperatures T1 (ambient temperature- $30-37^{\circ} \mathrm{C}$ ) and T2 (refrigeration temperature- $5-7^{\circ} \mathrm{C}$ ) for different time intervals i.e. $0,30,60,90,120,150$ and 180 days respectively. Thus there are 14 combinations of treatments under study were- P0/T1, P0/T2, P1/T1, P1/T2, P2/T1, $\mathrm{P} 2 / \mathrm{T} 2, \mathrm{P} 3 / \mathrm{T} 1, \mathrm{P} 3 / \mathrm{T} 2, \mathrm{P} 4 / \mathrm{T} 1, \mathrm{P} 4 / \mathrm{T} 2, \mathrm{P} 5 / \mathrm{T} 1, \mathrm{P} 5 / \mathrm{T} 2, \mathrm{P} 6 / \mathrm{T} 1$ and $\mathrm{P} 6 / \mathrm{T} 2$ for 180 days of storage period. Among above 6 (B1 to B6) different blanching treatments, the successful blanching treatment was $\mathrm{B} 6-100^{\circ} \mathrm{C}$ for $60 \mathrm{sec}$. followed by dipping into $0.25 \%$ potassium metabisulphite for 10 minutes. Among above 14 different treatments, the treatments which remained microbial safe till 180 days of storage period were P4/T1 [YMC (Yeast and mold count)- 23.14count/ gm, TPC (Total plate count)-46.86 cfu/ml, E.coli(Escherichia coli) -Nil], P5/T2 (YMC- 17.71 count/gm, TPC- $14.42 \mathrm{cfu} /$ $\mathrm{ml}$, E.coli-Nil) and P4/T2 (YMC - 8.43 count/gm, TPC-23.43 cfu/ml, E.coli-Nil). Among these three (P4/T1, P5/T2 and $\mathrm{P} 4 / \mathrm{T} 2$ ) treatments, $\mathrm{P} 4 / \mathrm{T} 2$ was scored highest in sensory evaluation (color and appearance - 8.0 , flavor and texture8.2, Body and texture-8.14 and overall acceptability-8.0) in 180 days of storage period. So best hurdle treatment for preservation of cauliflower till 180 days of storage period was P4/T2.
\end{abstract}

Keyword: Hurdle; YMC; TPC; E.coli; ppm

\section{Introduction}

India is a leading vegetable producing country in the world with the production of 113.5 million tons. The country is blessed with the unique gift of nature of diverse climates and distinct seasons, which makes it possible to grow a variety of vegetables. The overall productivity of vegetables is 14.4 tons per hectare. The production of vegetables has taken a big jump due to advent of many hybrid varieties. But our market strategy is not equipped with the handling of large quantity of vegetables as a result quantities of vegetables get spoil. Post harvest losses of horticulture crops are immense. It varies between $5-39 \%$ of the total production. The shelf life of perishable vegetables is very low. In brinjal, cauliflower and chilly post harvest losses were found to be high [1].

Preservation involves action taken to maintain foods with desired properties or nature for as long as possible. It lies at the heart of Food Science and Technology and it is the main purpose of Food Processing [2]. The Hurdle concept was first introduced by Professor Lothar Leistner et al. [3]. The hurdle governs many preservation processes. Intense heat $(\mathrm{F})$ preserves canned foods, low water activity prevents microbial growth in dried products, low $\mathrm{pH}$ is responsible for prolonged shelf life of fermented foods. This preservation technique is also called combination techniques or barrier technology or metodascombinados in Spanish, technologia degli ostacoli in Italian, Hurdle Technology in German. Potential hurdles for food preservation are - Temperature (High or Low), pH (High or Low), Water activity (High or Low),
Modified atmosphere $\left(\mathrm{Co}_{2}, \mathrm{~N}_{2}\right.$ etc), Packaging (Vacuum packaging, aseptic packaging, edible coating etc.), Radiation (UV, microwave, irradiation etc), Preservatives (Class I and II). Hurdle Technology is a technology by which 2 or more hurdles are employed in a suitable combination and every hurdle is used at an optimum level so that damage to the overall quality of food is kept to the minimum. Hurdle Technology foods are defined as "Products whose shelf-life and the microbial safety are extended by use of several factors none of which individually would be totally lethal towards spoilage or pathogenic microbes" [4].

\section{Objectives of the research}

- To develop a suitable technology for blanching of cauliflower to inactivate the catalase and peroxidase enzyme.

*Corresponding author: Jyoti Sinha, Centre of Food Technology University of Allahabad, Allahabad, U.P., India, Tel: 9336122125; E-mail: jyoti.sinha82@rediffmail.com

Received July 15, 2013; Accepted September 16, 2013; Published September 25, 2013

Citation: Sinha J, Gupta E, Tripathi P, Chandra R (2013) Microbial and Sensory Stability of Cauliflower for 180 Days Preserved Through Hurdle Technology. J Food Process Technol 4: 265. doi:10.4172/2157-7110.1000265

Copyright: ( 2013 Sinha J, et al. This is an open-access article distributed unde the terms of the Creative Commons Attribution License, which permits unrestricted use, distribution, and reproduction in any medium, provided the original author and source are credited. 
- To develop a suitable hurdle technology (appropriate concentration and combinations of preservatives, storage temperatures and storage periods) for blanched cauliflower.

- To study the effect of hurdle technology (different concentration and combinations of preservatives, storage temperatures and storage periods) on the microbial content of preserved cauliflower.

- To study the effect of hurdle technology (different concentration and combinations of preservatives, storage temperatures and storage periods) on the sensory properties of preserved cauliflower.

\section{Materials and Methods}

\section{Materials used in preservation}

Cauliflower cords: The cords of cauliflower were procured from local market of Naini.

Chemicals used in blanching and preservation: Food grade (potassium metabisulphate, sodium benzoate and citric acid) chemicals were used.

Polyethylene pouches: Food grade pouches were used.

Reagents used in analysis: Analytical grade reagents were used.

\section{Method of preservation}

First cauliflower head (white curds) after sorting, were cut into $5 \times 3 \times 3 \mathrm{~cm}$. pieces with sharp edged stainless steel knife, then thoroughly washed in tap water and distilled water. After washing, blanched at different- $\mathrm{B} 1-98^{\circ} \mathrm{C}$ for $30 \mathrm{sec}$., B2- $98^{\circ} \mathrm{C}$ for 60 sec., B3$99^{\circ} \mathrm{C}$ for 30 sec., $\mathrm{B} 4-99^{\circ} \mathrm{C}$ for 60 sec., $\mathrm{B} 5-100^{\circ} \mathrm{C}$ for 30 sec., $\mathrm{B} 6-100^{\circ} \mathrm{C}$ for $60 \mathrm{sec}$., followed by dipping into $0.25 \%$ potassium metabisulphite for 10 minutes. Among above 6 (B1 to B6) treatments, successful blanching treatment was selected. Then blanched cauliflower were steeped into different concentrations and combinations of preservatives - P0 (Control sample- fresh without treatment), P1 (8\% Salt+500 ppm Potassium metabisulphite +100 ppm Sodium benzoate), P2 (10\% Salt +400 ppm Potassium metabisulphite +200 ppm Sodium benzoate), P3 (12\% Salt +300 ppm Potassium metabisulphite +300 ppm Sodium benzoate), P4 ( $8 \%$ Salt $+0.3 \%$ Citric acid +300 ppm Potassium metabisulphite +300 ppm Sodium benzoate), P5 (10\% Salt $+0.2 \%$ Citric acid $+400 \mathrm{ppm}$ Potassium metabisulphite $+200 \mathrm{ppm}$ Sodium benzoate) and P6 (12\% Salt $+0.1 \%$ Citric acid +500 ppm Potassium metabisulphite $+100 \mathrm{ppm}$ Sodium benzoate). Steeped cauliflower were further aseptically packed into food grade polyethylene pouches and stored at two different level of temperatures- T1 (ambient temperature 30 to $37^{\circ} \mathrm{C}$ ) and $\mathrm{T} 2$ (refrigeration temperatures -5 to $7^{\circ} \mathrm{C}$ ) for different time intervals i.e. $0,30,60,90,120,150$ and 180 days respectively. Thus there are 14 combinations of treatments under study were-P0/T1, P0/ T2, P1/T1, P1/T2, P2/T1, P2/T2, P3/T1, P3/T2, P4/T1, P4/T2, P5/T1, $\mathrm{P} 5 / \mathrm{T} 2, \mathrm{P} 6 / \mathrm{T} 1$ and $\mathrm{P} 6 / \mathrm{T} 2$ for 180 days of storage period (where $\mathrm{P} 0, \mathrm{P} 1$, P2, P3, P4, P5 and P6 are different combination of preservatives and $\mathrm{T} 1$ and $\mathrm{T} 2$ are different level of temperatures, all are explained above). All combinations of treatments were analyzed for their microbial and sensory properties and data obtained after analysis were statistically analyzed.

\section{Analysis performed}

Blanching test: Catalase and peroxidase test [5].
Microbial analysis: YMC, TPC and E-coli were determined by Conventional method [6].

Sensory analysis: Sensory properties (color, flavor, texture and overall acceptability) were determined by 9 Point Hedonic Scale method [7].

Physical test: Water activity was determined by using Water Activity Meter [8]. $\mathrm{pH}$ was determined by using $\mathrm{pH}$ meter (Electronic Corporation of India, Model 5652) as per procedure described in Ministry of Health and Family Welfare, Manual of methods of analysis of foods- Fruit and Vegetable Products [9].

Statistical analysis: Obtained data were analyzed for ANOVA (3 Way Classification) and critical difference (C.D.) technique, described by Imran and Coover [10]. In statistical analysis, data used were average of replicates, total no. of treatments combinations were 14 - P0/T1, P0/ T2, P1/T1, P1/T2, P2/T1, P2/T2, P3/T1, P3/T2, P4/T1, P4/T2, P5/T1, P5/T2, P6/T1, P6/T2 (where P0, P1, P2, P3, P4, P5 and P6 are different combination of preservatives and $\mathrm{T} 1$ and $\mathrm{T} 2$ are different level of temperatures, all are explained in Method of preservation). Level of significance was checked at $5 \%$ probability level.

\section{Results}

\section{Blanching test of cauliflower}

Result of blanching treatment are given in Table 1. The successful blanching treatment (catalase and peroxidase test found negative) was $\mathrm{B} 6-100^{\circ} \mathrm{C}$ for $60 \mathrm{sec}$., followed by dipping into $0.25 \%$ potassium metabisulphite for 10 minutes

\section{Microbial analysis of preserved cauliflower}

Scores of microbial analysis (YMC, TPC and E.coli) of preserved cauliflower are given in Table 2.

YMC analysis: Treatments in which average YMC were found lowest with a storage period of 180 days are P4/T1 23.14 count/gm), P5/ T2 (17.71 count/gm) and P4/T2 (8.43 count/gm). There were significant difference between YMC of treated samples due to combination of preservatives and storage temperatures while there was not significant difference due to days of storage at $5 \%$ probability levels.

TPC analysis: Average TPC count of the treatment P5/T2 (14.42 $\mathrm{cfu} / \mathrm{ml}$ ) was found lowest in comparison of other treatments in a storage period of 180 days. There were significant difference between TPC scores of treated samples due to combination of preservatives and storage temperatures while there was not significant difference due to days of storage at $5 \%$ probability levels.

E. coli: E. coli count of fresh and preserved samples were found Nil.

\begin{tabular}{|c|c|c|}
\hline Treatments of Blanching & Catalase Test & Peroxidase Test \\
\hline B1 & Positive & Positive \\
\hline B2 & Positive & Positive \\
\hline B3 & Positive & Positive \\
\hline B4 & Positive & Positive \\
\hline B5 & Positive & Positive \\
\hline B6 & Negative & Negative \\
\hline
\end{tabular}

B1, B2, B3, B4, B5, B6 are different treatments of Blanching

Table 1: Enzymatic activity (presence of catalase \& peroxidase enzyme) in blanched cauliflower followed by dipping into $0.25 \%$ potassium metabisulphite for 10 minutes. 


\begin{tabular}{|c|c|c|c|c|}
\hline \multicolumn{2}{|c|}{ Treatments with its Shelf life(in days) } & \multirow{2}{*}{$\begin{array}{c}\text { YMC/gm } \\
32.17^{*}\end{array}$} & \multirow{2}{*}{$\begin{array}{c}\text { TPC(cfu/ml) } \\
20.14^{*}\end{array}$} & \multirow{2}{*}{$\begin{array}{c}\text { E. coli } \\
\text { Nil }\end{array}$} \\
\hline $\mathrm{P} 0 / \mathrm{T} 1$ & -180 & & & \\
\hline $\mathrm{P} 0 / \mathrm{T} 2$ & -180 & $32.17^{*}$ & $20.14^{*}$ & - do - \\
\hline $\mathrm{P} 1 / \mathrm{T} 1$ & -30 & 65 & 47.33 & - do - \\
\hline $\mathrm{P} 1 / \mathrm{T} 2$ & -60 & 51 & 31 & - do - \\
\hline $\mathrm{P} 2 / \mathrm{T} 1$ & -60 & 35.75 & 36.25 & - do - \\
\hline $\mathrm{P} 2 / \mathrm{T} 2$ & -90 & $26.8^{*}$ & $25^{*}$ & - do - \\
\hline P3/T1 & -90 & 52 & 40.4 & - do - \\
\hline $\mathrm{P} 3 / \mathrm{T} 2$ & -120 & 47.5 & $25.5^{*}$ & - do - \\
\hline $\mathrm{P} 4 / \mathrm{T} 1$ & -180 & $23.14^{*}$ & 46.86 & - do - \\
\hline $\mathrm{P} 4 / \mathrm{T} 2$ & -180 & $8.43^{*}$ & $23.43^{*}$ & - do - \\
\hline P5/T1 & -150 & 40.29 & 34.28 & - do - \\
\hline P5/T2 & -180 & $17.71^{*}$ & $14.42^{*}$ & - do - \\
\hline P6/T1 & -120 & $28.45^{*}$ & $27.33^{*}$ & - do - \\
\hline P6/T2 & -150 & $26.5^{*}$ & $21.57^{*}$ & - do - \\
\hline
\end{tabular}

YMC/gm-Yeast \& mold count/gm; TPC (cfu/ml)-Total plate count (colony formation unit/ml); E. coli- Escherichia coli; All values are MEAN; *Significant values.

Table 2: Scores of microbial analysis (YMC, TPC \& E. coli) of preserved cauliflower in different treatments with its shelf life.

\section{Sensory analysis of preserved cauliflower}

Scores of sensory analysis are given in Table 3. In preserved samples, treatment $\mathrm{P} 4 / \mathrm{T} 2$ scored highest in color and appearance (8.0), flavor and taste (8.2), body and texture (8.14) and overall acceptability (8.0) with a storage period of 180 days. There were significant difference between scores of color and appearance, flavor and taste, body and texture and overall acceptability scores of treated samples due to combination of preservatives and days of storage while there was not significant difference due to storage temperatures at $5 \%$ probability levels.

\section{Physical analysis of preserved cauliflower}

Scores of water activity and $\mathrm{pH}$ of treated samples are given in Table 4. Lowest water activity $(0.63 \%)$ and $\mathrm{pH}$ (3.3) were found in $\mathrm{P} 4 / \mathrm{T} 2$ in a storage period of 180 days. There were significant difference between water activity and $\mathrm{pH}$ scores of treated samples due to combination of preservatives and storage temperatures while there was not significant difference due to days of storage at $5 \%$ probability levels.

\section{Discussion}

\section{Blanching test}

During blanching the catalase and peroxidase enzyme was inactivated through treatment $\mathrm{B} 6$ (blanching cauliflower pieces at $100^{\circ} \mathrm{C}$ for $60 \mathrm{sec}$. in boiling water) followed by dipping into $0.25 \%$ potassium metabisulphite for 10 minutes. The results are in agreement of previous finding of Singh [11]. Srivastava and Nath [12] also observed the same result with no difference in blanching time followed by steeping in different concentration of potassium metabisulphite like $0.25 \%, 0.5 \%$ and $0.75 \%$.

\section{Microbial analysis}

YMC analysis: In case of YMC analysis, the increase in YMC was observed in all treatments at both the temperatures. In most of the treatments YMC were found above from the standard (as per Food Safety and Standard Authority of India, 2006-Yeast/Mold not more than 100 count/gm) [13] with increase in storage period, which may be attributed during addition of preservatives or during packaging which could have been a carrier of microbes. While in some treatments counts remained under control as per above mentioned standard till 180 days of storage, it might be due to better handling procedure or different concentration and combinations of class I and II preservatives and low temperature of storage. The results are in agreement of previous finding of Gould [14], observed that the food preservation through hurdle technology cause interference with the homeostasis of yeast and mold. Alzamora et al. [15], also noticed that yeast and mould counts remained below $100 \mathrm{cfu} / \mathrm{gm}$ during 4 months of storage of pineapple slices preserved through hurdle technology at $5^{\circ} \mathrm{C}$. Lopez-Malo et al. [16], preserved papaya through hurdles technology, found yeast and mold counts $<10 \mathrm{CFU} / \mathrm{g}$ during 5 months storage at $25^{\circ} \mathrm{C}$.

TPC analysis: In case of TPC analysis, the increase in count was observed in all treatments at both the temperatures, while TPC of all the preserved cauliflower found within standard (as per Food Safety and Standard Regulation, 2010- TPC not more than $1000 \mathrm{cfu} / \mathrm{ml}$ ) [13] till 180 days of storage period but because of YMC of all the preserved sample (except treatments- P4/T1, P5/T2 and P4/T2) were found above from the above mentioned standard of YMC in 180 days of storage period so all the preserved samples were discarded one by one on the basis of their YMC and not considered for further analysis of sensory. The results of TPC are in agreement of previous findings of Alzamora et al. [15] noticed that TPC remain below $100 \mathrm{cfu} / \mathrm{ml}$ during 4 months of storage of pineapple slices preserved through hurdle technology

\begin{tabular}{|c|c|c|c|c|c|}
\hline \multicolumn{2}{|c|}{$\begin{array}{l}\text { Treatments with its } \\
\text { Shelf life (in days) }\end{array}$} & \multirow{2}{*}{$\begin{array}{l}\text { Flavor \& Body \& } \\
\text { Overall acceptability } \\
9^{\star}\end{array}$} & \multirow{2}{*}{\begin{tabular}{|l|}
$\begin{array}{l}\text { Color \& } \\
\text { appearance }\end{array}$ \\
$9^{*}$
\end{tabular}} & \multirow{2}{*}{$\begin{array}{l}\text { Taste } \\
9^{*}\end{array}$} & \multirow{2}{*}{$\begin{array}{l}\text { Texture } \\
9^{*}\end{array}$} \\
\hline $\mathrm{P} 0 / \mathrm{T} 1$ & -180 & & & & \\
\hline $\mathrm{P} 0 / \mathrm{T} 2$ & -180 & $9^{*}$ & $9^{*}$ & $9^{*}$ & $9^{*}$ \\
\hline $\mathrm{P} 1 / \mathrm{T} 1$ & -30 & 7 & $7.3^{*}$ & 7 & 7 \\
\hline $\mathrm{P} 1 / \mathrm{T} 2$ & -60 & 6.66 & $7.8^{*}$ & $7.2^{*}$ & 7 \\
\hline $\mathrm{P} 2 / \mathrm{T} 1$ & -60 & 6 & 6.66 & 6.66 & 6 \\
\hline $\mathrm{P} 2 / \mathrm{T} 2$ & -90 & 6 & 6.75 & 7 & 6.25 \\
\hline $\mathrm{P} 3 / \mathrm{T} 1$ & -90 & 6.25 & 7 & 6.75 & 6.25 \\
\hline $\mathrm{P} 3 / \mathrm{T} 2$ & -120 & 6.6 & $7.4^{*}$ & 6.8 & 6.8 \\
\hline $\mathrm{P} 4 / \mathrm{T} 1$ & -180 & $7.14^{*}$ & $7.43^{*}$ & $7.28^{*}$ & $7.14^{*}$ \\
\hline $\mathrm{P} 4 / \mathrm{T} 2$ & -180 & $8^{*}$ & $8.2^{*}$ & $8.14^{*}$ & $8^{*}$ \\
\hline $\mathrm{P} 5 / \mathrm{T} 1$ & -150 & 7 & $7.16^{*}$ & $7.16^{*}$ & 7 \\
\hline $\mathrm{P} 5 / \mathrm{T} 2$ & -180 & $7.71^{*}$ & $8.14^{*}$ & $7.42^{*}$ & $7.85^{*}$ \\
\hline P6/T1 & -120 & 6 & 6.8 & 6.6 & 6.6 \\
\hline $\mathrm{P} 6 / \mathrm{T} 2$ & -150 & $7.16^{*}$ & $7.5^{*}$ & 7 & $7.3^{*}$ \\
\hline
\end{tabular}

All values are MEAN; *Significant values

Table 3: Scores of sensory analysis of preserved cauliflower in different treatments with its shelf life.

\begin{tabular}{|l|c|c|c|}
\hline \multicolumn{2}{|l|}{ Treatments with its Shelf life(in days) } & Water activity (\%) & pH \\
\hline P0/T1 & -180 & $0.98^{*}$ & $6.2^{*}$ \\
\hline P0/T2 & -180 & $0.98^{*}$ & $6.2^{*}$ \\
\hline P1/T1 & -30 & 0.78 & 4.5 \\
\hline P1/T2 & -60 & 0.74 & 4.2 \\
\hline P2/T1 & -60 & 0.71 & 4.4 \\
\hline P2/T2 & -90 & $0.69^{*}$ & 4.14 \\
\hline P3/T1 & -90 & 0.76 & 4.2 \\
\hline P3/T2 & -120 & 0.74 & 4.0 \\
\hline P4/T1 & -180 & $0.67^{*}$ & $3.5^{*}$ \\
\hline P4/T2 & -180 & $0.63^{*}$ & $3.3^{*}$ \\
\hline P5/T1 & -150 & 0.74 & $3.9^{*}$ \\
\hline P5/T2 & -180 & $0.66^{*}$ & $3.7^{*}$ \\
\hline P6/T1 & -120 & $0.69^{*}$ & 4.04 \\
\hline P6/T2 & -150 & $0.67^{*}$ & $3.8^{*}$ \\
\hline
\end{tabular}

All values are MEAN; *Significant values.

Table 4: Scores of Water activity (\%) \& pH of preserved cauliflower in different treatments with its shelf life. 
at $5^{\circ} \mathrm{C}$. Chirife and Guillermo [17] stated that food preservation by combined methods consists of a combination of various parameters also called hurdles may act synergistically to inhibit (or retard) bacterial growth resulting in stable products at room temperature. Barwal et al. [18], preserved cauliflower by using hurdle technology, by different concentrations and combinations of salt (5, 10, 15\%), potassium metabisulphite (KMS-0.2\%), and citric acid (1.0\%) after blanching. The cauliflower steeped in 10 and $15 \%$ salt containing $0.2 \%$ KMS were chemically, sensory microbial safe among all treatments during the entire period of storage.

E coli: In the present investigation E. coli were found to be absent in fresh as well as preserved cauliflower samples. This result is also supported by Food Safety and Standard Regulation 2010- E-colimust be Nil [13]. This indicates that the cauliflowers which were used in preservation were free from fecal contamination and also proper hygienic precautions had been taken during preservation as well as during packaging of treated samples.

\section{Sensory evaluation}

In sensory evaluation, the difference and decrease in color and appearance, flavor and taste, body and texture and overall acceptability scores were observed which may be attributed due to increase in microbial count with increase in storage period. But at the same time, treatments $\mathrm{P} 4 / \mathrm{T} 1, \mathrm{P} 5 / \mathrm{T} 2$ and $\mathrm{P} 4 / \mathrm{T} 2$ which remained microbial safe till 180 days of storage period were scored highest among all treatments and from 3 of them, P4/T2 was scored highest in sensory evaluation in 180 days of storage period. The results are in agreement of previous finding of Pruthi [19], the vegetables like potatoes, carrot, cauliflower, cabbage, bitter guard, peas, mushroom and animals foods (meat, fish and poultry) preserved in an acidified sulphited brine solution through steeping can be used for pickling or home cooking after leaching out the salt and acid. Barwal et al. [18] standardized the low cost and low energy processing technology for preservation of cauliflower involving different concentration and combination of salt (5-10\%), potassium metabisulphite $(0.2 \%)$ and citric acid (1\%) after blanching. The preserved cauliflower was accepted in sensory evaluation after 90 and 180 days of storage by reconstituted in running water for half an hour and evaluated for the preparation of pickle and pakora.

\section{Physical analysis}

In physical test, the reduction in water activity and $\mathrm{pH}$ of preserved sample were found as compare to initial or fresh commodity. Reduced water activity and $\mathrm{pH}$ were found effective for long time storage. The results are in agreement of previous finding of Vibhakara et al. [20], maintenance of $\mathrm{pH}<4.5$ helped in controlling multiplication and survival of spores and also helpful in achieving shelf stability. Low $\mathrm{pH}$ and water activity solutions are used as antimicrobial agent or as antioxidant to prevent browning, to reduce discoloration of pigments, and to protect against loss of flavor, changes in texture [21].

\section{Conclusion}

All the hurdles (treatments combination) were not effective for preservation of cauliflower till 180 days of storage period. Only 3 treatments - P4/T1, P4/T2 and P5/T2 were microbial safe till 180 days and among these 3, only $\mathrm{P} 4 / \mathrm{T} 2$ was found best in sensory evaluation sin 180 days of storage period.

\section{Acknowledgement}

I express my deep sense of gratitude for my advisor (Prof.) Dr. Ramesh Chandra, (Dean) Warner School Of Food and Dairy Technology, to all member of advisory committee - Dr. D.B. Singh, Dean of Horticulture Department, (Prof.) Dr. Sarita Sheikh, Dean of Halina School of Home Science, (Prof.) Dr. Sangeeta Upadhayay, Assistant Professor (Microbiology),Warner School Of Food and Dairy Technology, (Prof.) Dr. Ram Lal, Dean of Department of Statistics, Sam Higginbottom Institute of Agriculture, Technology and Sciences, Allahabad, for there sincere guidance, suggestions, constructive work and encouragement during the entire research work. Sincere thanks to Honorable Vice-Chancellor, Sam Higginbottom Institute of Agriculture, Technology and Sciences, Allahabad, for providing me necessary technical and financial facilities.

I want to acknowledge the immense help received from the scholars whose articles are cited and included in references of this manuscript. I also grateful to authors / editors / publishers of all those articles, journals and books from where the literature for this article has been reviewed and discussed.

\section{References}

1. Jayanthi M (2005) Innovative solution to extent the shelf life of fruits. Processed Food Industry 9: 37-38.

2. Barnettend M, Blanchfield JR (1995) What does preservation mean. Food Sci Technol 9: 93-112.

3. Lothar L (1978) Hurdle effect and energy saving. In: Downey WK, editors. Food Quality and Nutrition. 2nd ed. London: Applied Science Publishers.

4. Berwal JS (1994) Hurdle technology for shelf stable food products. Indian Food Industry 13: 40-43.

5. Ranganna S (2005) Catalase \& peroxidase test. In: Hand Book of Analysis and Quality Control for Fruit and Vegetable Products. New Delhi: Tata McGraw Hill Education Private Ltd, India.

6. Ranganna S (2005) General instruction for microbiological examination. In Hand Book of Analysis and Quality Control for Fruit and Vegetable Products. Tata McGraw Hill Education Private Ltd, India.

7. Ranganna S (2005) Sensory evaluation. In: Hand Book of Analysis and Quality Control for Fruit and Vegetable Products. Tata McGraw Hill Education Private Ltd, New York, USA.

8. Operator's manual AQUA LAB Series 4TE (2007) Water activity meter Decagon Devices.

9. Ministry of Health \& Family Welfare (2005) Manual of methods of analysis of foods: Fruit and Vegetable Products. New Delhi: Government of India.

10. Imran RL, Coover WB (1983) Statistical analysis. In: A modern approach to statistics. 2nd ed. New York, p. 120.

11. Singh A (2007) Studies on steeping preservation of vegetables, M.Sc. Thesis University of Allahabad, UP, India.

12. Srivastava PP, Nirarkar N (1985) Development of a process for drying fresh and brined cauliflower. J Food Sci Technol 22: 334 - 337.

13. Food Safety \& Standard Authority of India (Ministry of Health \& Family Welfare) (2010) Microbiological Requirements of Food Products.

14. Gould GW (1995) Interference in homeostasis. (3rd edn), Whitten bury R, Banks JG, editors. Homeostatic Mechanism in Microorganisms. Bath University Press.

15. Alzamora SM, Gerschenson LN, Cerrutti P, Rojas AM (1989) Shelf-stable pineapples for long-term non-refrigerated storage. 22: 233-236.

16. Lopez-Malo A, Palou E, Welti J, Corte P, Arias A (1994) Shelf-stable high moisture papaya minimally processed by combined methods. Food Res Int 27 : 545-553.

17. Chirife J, Guillermo J (1992) Some physico-chemical basis of food preservation by combined methods. Food Res Int 25: 389-396.

18. Barwal VS, Sharma R, Singh R (2005) Preservation of cauliflower by hurdle technology. J Food Sci Tech Mys 42: 26-30.

19. Pruthi JS (1963) Physiology, Chemistry and Technology of Passion Fruits. Adv Food Res 12: 203-282.

20. Vibhakara HS, Manjunath SS, Radhika MD, Gupta DK, Bawa AS (2005) Preservation technique for stabilizing high moisture spice based vegetables. $J$ Foods Sci and Technol 42: 434-437.

21. Wiley RC (1994) Preservation Methods for Minimally Processed Refrigerated Fruits and Vegetables. Minimally Processed Refrigerated Fruits \& Vegetables, Chapman \& Hall. 